\title{
Penerapan Soft Skill Coaching pada Penyusunan Aktualisasi (Studi Kasus pada Pelatihan Dasar CPNS Kabupaten Pulau Morotai)
}

\section{Implementation of Coaching Soft Skill in the Making of Actualization Project (Case Study on The Basic Training for Civil Servant Candidate of Morotai Island Regency)}

\author{
Najemiah M. Amin \\ Badan Pengembangan Sumber Daya Manusia Provinsi Maluku Utara \\ Jl. Raya 40 Kel. Guraping Sofifi, Maluku Utara \\ najemiahmuhammadamin@gmail.com
}

\begin{abstract}
Naskah diterima tanggal 3 November 2021. Naskah direvisi tanggal 26 Desember 2021.
Naskah disetujui tanggal 29 Desember 2021.
\end{abstract}

\begin{abstract}
Abstrak
Latar belakang penelitian adalah peserta pelatihan dasar mengalami kesulitan dalam memunculkan ide atau gagasan serta kegiatan-kegiatan yang akan dilakukan, padahal seharusnya peserta tidak harus mengalami kesulitan dalam penentuan gagasan aktualisasi karena berkaitan dengan tugas dan fungsi peserta. Maka penelitian bertujuan menemukan pertama, mengetahui prinsip coaching penulisan aktualisasi dan kedua mengetahui penerapan soft skill coaching dalam penulisan aktualisasi. Metode penelitian yang digunakan dalam penelitian ini adalah metode kuantitatif. Sampel yang digunakan dalam penelitian adalah alumni Pelatihan Dasar Calon Pegawai Negeri Sipil Golongan III Kabupaten Pulau Morotai sebanyak 40 orang. Teknik pengumpulan data yang digunakan dalam penelitian adalah studi kepustakaan, penyebaran kuisioner dan wawancara. Teknik analisis data dilakukan dengan metode deskriptif kualitatif. Hasil penelitian diketahui bahwa, pertama prinsip coaching penulisan aktualisasi sudah berjalan dengan baik namun diperlukan penguatan pada aspek coach lebih banyak mendengar serta berkomitmen menyusun strategi kedepannya. Kedua, penerapan soft skill coaching dalam penulisan aktualisasi sudah berjalan dengn baik tetapi masih perlu penguatan pada aspek perilaku sopan santun. Maka secara keseluruhan diperlukan peningkatan kompetensi coaching secara berkesinambungan.
\end{abstract} Kata Kunci: Soft skill, Coaching, Aktualisasi

\section{Abstract}

The background of the research is that basic training participants have difficulty in generating ideas or ideas as well as the activities to be carried out, even though participants should not have to experience difficulties in determining the idea of actualization because it is related to the tasks and functions of the participants. This research aims to find first, to 
know the principles of coaching writing actualization and secondly to find out the application of soft skills coaching in writing actualization. The research method used in this study is a quantitative method. The sample used in this study was 40 people of Basic Training Alumni of Candidates for Civil Servants Group III Morotai Island Regency. Data collection techniques used in this research are literature study, questionnaire distribution and interviews. The data analysis technique was carried out using a qualitative descriptive method. The results of the study show that, firstly, the principle of coaching writing actualization has been going well, but it is necessary to strengthen the aspect of the coach listening more and being committed to formulating future strategies. Second, the application of soft skills coaching in writing actualization has been going well but still needs to be strengthened in the aspect of polite behavior. So overall it is necessary to improve coaching competence on an ongoing basis.

Keywords: Soft skills, Coaching, Actualization

\section{PENDAHULUAN}

Berdasarkan Undang-Undang Nomor 5 Tahun 2014 tentang Aparatur Sipil Negara, PNS atau yang sekarang lebih populer dengan sebutan ASN (Aparatur Sipil Negara), dalam pengelolaannya diatur dalam Manajemen Aparatur Sipil Negara yaitu Sistem Manajemen Kepegawaian yang meliputi sistem perencanaan, pengembangan karier, penggajian, dan batas usia pensiun. Manajemen ASN ini diharapkan mampu memperbaiki manajemen pemerintahan yang berorientasi pada pelayanan publik, sebab Pegawai Negeri Sipil (PNS) tidak lagi berorientasi melayani atasannya, melainkan masyarakat, berbasis pada manajemen sumber daya manusia dan mengedepankan sistem merit menuju terwujudnya birokrasi pemerintahan yang profesional.

Dalam rangka beraktualisasi melaksanakanan tugas dan kewajibannya, Pegawai Negeri Sipil dituntut untuk mampu berpijak kepada Nilai Dasar Profesi Pegawai Negeri Sipil, yang terdiri dari Akuntabilitas PNS, Komitmen Mutu, Nasionalisme, Etika Publik dan Anti Korupsi atau yang lebih dikenal dengan sebutan "ANEKA". Kelima Nilai dasar itu sangat menentukan berhasil tidaknya tujuan yang ingin dicapai dan di bangun menurut Undang-Undang Nomor 5 Tahun 2014 tentang Aparatur Sipil Negara, yaitu ASN yang Berintegritas, Profesional, Netral dan Bebas dari Intervensi Politik, Bersih dari KKN dan mampu menyelenggarakan pelayanan publik bagi masyarakat dan mampu menjalankan peran sebagai unsur perekat persatuan dan kesatuan bangsa berdasarkan Pancasila dan UUD Negara RI 1945.

Untuk dapat menjalankan tugas pelayanan publik, tugas pemerintahan dan tugas pembangunan tertentu, Pegawai ASN harus memiliki profesi dan Manajemen ASN yang 
berdasarkan pada Sistem Merit atau perbandingan antara kualifikasi, kompetensi dan kinerja yang dibutuhkan oleh jabatan dengan kualifikasi, kompetensi dan kinerja yang dimiliki oleh calon dalam rekruitmen, pengangkatan, penempatan, dan promosi pada jabatan yang dilaksanakan secara terbuka dan kompetitif, sejalan dengan tata kelola pemerintahan yang baik.

Sejalan dengan hal itu Pelatihan Dasar (Latsar) CPNS pola baru bertujuan agar PNS setelah mengikuti Latsar, peserta mampu mengaplikasikan nilai-nilai dasar akuntabilitas, nasionalisme, etika publik, komitmen mutu, dan anti korupsi (ANEKA) pada instansi masing-masing. Adapun tujuan dari aplikasi nilai-nilai dasar adalah untuk membentuk PNS yang profesional, berkarakter nilai-nilai dasar profesi PNS, sehingga mampu melaksanakan tugas dan perannya secara profesional sebagai pelayan masyarakat. Untuk meningkatkan kualitas sumber daya manusia yang mampu menganalisis setiap permasalahan dalam penerapan pola pembelajaran sesuai dengan kondisi dan situasi, manakala nilai-nilai ANEKA tersebut diaplikasikan di lingkungan tempat kerja dan dapat memberikan solusi yang terbaik.

Proses coaching aktualisasi nilai-nilai dasar profesi PNS bagi peserta Latsar golongan III memegang peranan yang penting dan sangat menentukan dalam merancang kegiatankegiatan yang akan diaktualisasikan di tempat tugas sebagai miniatur tugas pokok dan fungsinya sebagai Pegawai Negeri Sipil. Untuk menggali ide-ide, mengembangkan kemampuan seorang coachee dan bagaimana mereka melaksanakannya itulah metode pembelajaran berbasis soft skills sangat diperlukan oleh seorang coach, sehingga seorang coachee mampu menemukan, mengembangkan dan melaksanakan dengan cara/teknik yang akan dipilih dalam mengaktualisasikan kegiatan-kegiatan yang dipilih dengan potensi yang dimilikinya sendiri.

Penelitian ini mencoba untuk melakukan identifikasi realita di lapangan tentang penerapan metode pembelajaran berbasis soft skills dalam proses coaching Peserta Latsar Golongan III Kabupaten Pulau Morotai sehingga mampu menampilkan gambaran kondisi secara lebih nyata. Masalah awal yang teridentifikasi adalah Peserta Latsar mengalami kesulitan dalam memunculkan ide-ide, kegiatan-kegiatan yang akan diaktualisasikan dan bagaimana cara/teknik yang digunakan pada proses aktualisasi Nilai-Nilai Dasar Profesi Pegawai Negeri Sipil dikarenakan seorang coach belum menerapkan metode Pembelajaran berbasis soft skills sebagai salah satu metode yang cukup penting untuk digunakan oleh 
Coach dalam menentukan keberhasilan proses coaching. Proses coaching memerlukan kerjasama, komunikasi yang efektif tentu saja memerlukan soft skill dalam rangkaian interaksi antara peserta (coachee), coach, mentor dan penyelenggara pelatihan. Menurut Mulyono (2011: 99), soft skills merupakan komplemen dari hard skills. Jenis keterampilan ini merupakan bagian dari kecerdasan intelektual seseorang, dan sering dijadikan syarat unutk memperoleh jabatan atau pekerjaan tertentu.

Berdasarkan latar belakang yang telah diuraikan di atas, maka menjadi permasalahan utama dalam penelitian diantaranya masih kurangnya metode pendekataan proses choaching. Dengan demikian, dari permasalahan tersebut diatas dapat dirumuskan masalah dalam penelitian adalah a) bagaimana prinsip coaching penulisan aktualisasi? b) bagaimana penerapan soft skill coaching dalam penulisan aktualisasi?

\section{TINJAUAN TEORI}

\section{Pengertian Soft Skills}

Menurut Elfindri et. al. (2011: 67), Soft skills merupakan keterampilan dan kecakapan hidup, baik untuk sendiri, berkelompok, atau bermasyarakat, serta dengan Sang Pencipta. Dengan mempunyai soft skills membuat keberadaan seseorang akan semakin terasa di tengah masyarakat. Keterampilan akan berkomunikasi, keterampilan emosional, keterampilan berbahasa, keterampilan Tulis miring istilah asing berkelompok, memiliki etika dan moral, santun dan keterampilan spiritual. Lanjutnya, semua sifat yang menyebabkan berfungsinya hard skills yang dimiliki. Soft skills dapat menentukan arah pemanfaatan hard skills. Jika seseorang memilikinya dengan baik, maka ilmu dan keterampilan yang dikuasainya dapat mendatangkan kesejahteraan dan kenyamanan bagi pemiliknya dan lingkungannya. Sebaliknya, jika seseorang tidak memiliki soft skills yang baik, maka hard skills dapat membahayakan diri sendiri dan orang lain. Sejalan dengan pendapat Elfindri, Mulyono (2011: 99), menjelaskan bahwa soft skills merupakan komplemen dari hard skills. Jenis keterampilan ini merupakan bagian dari kecerdasan intelektual seseorang, dan sering dijadikan syarat unutk memperoleh jabatan atau pekerjaan tertentu.

Sementara menurut Goleman (2005) secara garis besar soft skills merupakan gabungan kemampuan intrapersonal dan kemampuan interpersonal. Kemampuan intrapersonal meliputi kesadaran diri atau self awareness (mencakup kepercayaan diri, penilaian diri, sifat dan preferensi, serta kesadaran emosional), serta kemampuan diri atau self skill (perkembangan diri, pengendalian diri, kepercayaan, kekhawatiran, manajemen waktu, 
proaktivitas, dan hati nurani). Sementara itu, kemampuan interpersonal meliputi kesadaran sosial atau social awareness (kesadaran politik, mengembangkan orang lain, memanfaatkan keragaman, orientasi pelayanan, dan empati) dan kemampuan sosial atau social skill (kemampuan kepemimpinan, pengaruh, komunikasi, manajemen konflik, kerjasama, sinergi dan kemampuan berorganisasi).

Pendapat Goleman sesuai dengan Aribowo sebagaimana dikutip oleh Sailah (2008: 17), menyebutkan soft skills adalah keterampilan seseorang dalam berhubungan dengan orang lain (termasuk dengan dirinya sendiri). Atributs of skills, dengan demikian meliputi nilai yang dianut, motivasi, perilaku, kebiasaan, karakter dan sikap. Atribut soft skills ini dimiliki oleh setiap orang dengan kadar yang berbeda-beda, dipengaruhi oleh kebiasaan berfikir, berkata, bertindak dan bersikap. Namun, atribut ini dapat berubah jika yang bersangkutan mau merubahnya dengan cara berlatih membiasakan diri dengan hal-hal yang baru. Aribowo membagi soft skills atau people skills menjadi dua bagian, yaitu intrapersonal skills dan interpersonal skills. Intrapersonal skills adalah keterampilan seseorang dalam mengatur diri sendiri. Intrapersonal skills sebaiknya dibenahi terlebih dahulu sebelum seseorang mulai berhubungan dengan orang lain.

Dari berbagai definisi tentang soft skill dapat dirumuskan bahwa pada dasarnya soft skills merupakan kemampuan yang sudah melekat pada diri seseorang, tetapi dapat dikembangkan dengan maksimal dan dibutuhkan dalam dunia pekerjaan sebagai pelengkap dari kemampuan hard skills. Keberadaan antara hard skills dan soft skills sebaiknya seimbang, seiring, dan sejalan.

\section{Pengertian Coaching.}

Menurut Whitmore (1997:14) di dalam bukunya yang berjudul Performance Coaching, menyatakan bahwa coaching adalah pembinaan yang membuka potensi seseorang untuk memaksimalkan kinerja mereka sendiri,yang membantu mereka untuk belajar daripada mengajar mereka.

Menurutnya, coaching berarti:

1. Mengakses potensial

2. Memfasilitasi individu untuk membuat perubahan yangdiperlukan

3. Memaksimalkan kinerja

4. Membantu orang memperoleh keterampilan dan mengembangkan 
5. Menggunakan teknik komunikasi khusus

Menurut Stone (2007:11) coaching adalah proses dimana individu mendapatkan keterampilan, kemampuan, dan pengetahuan yang mereka butuhkan untuk mengembangkan diri secara profesional dan menjadi lebih efektif dalam pekerjaan mereka. Ketika individu mendapatkan coaching dari atasan, mereka dapat meningkatkan kinerja mereka baik dalam saat ini, dan juga meningkatkan potensi mereka untuk berbuat lebih banyak di masa depan.

Menurut Salim (2014:2) coaching adalah bagaimana membantu seseorang menemukan apa yang diinginkan dari posisi dimana dia sekarang,dengan menggali sumber daya apa saja yang dibutuhkan, sikap mental yang harus dibangun dan teknik-teknik yang cocok dalam mengimplementasikannya. Morrison (1971:65) coaching adalah sesuatu yang harus dilakukan supervisor dalam waktu yang lama, yang menindaklanjuti perkembangan individu dalam hubungannya dengan pekerjaan mereka.

Jaques dan Clement (1994:195) menyatakan definisi coaching adalah "percakapan terstruktur yang menggunakan informasi tentang kinerja yang nyata antara seorang atasan dengan seorangindividu (atau tim) yang menghasilkan kinerja yang lebih tinggi." Merujuk pada definisi tersebut di atas, bentuk dari coaching adalah percakapan dan membantu orang yang dibimbing untuk meningkatkan kinerjanya. Coaching juga dapat dilakukan dimanapun apakah di kantor atau di lapangan, formal ataupun tidak formal.

Menurut Jaques, coaching terhadap karyawan/bawahan harus merupakan bagian dari aktivitas harian seorang atasan. Coaching bisa dalam bentuk berbagi pengetahuan, keterampilan dan pengalaman yang berkaitan dengan pekerjaan karyawan. Efektivitas coaching selain ditentukan oleh peran coach juga ditentukan oleh model coaching yang digunakan. Model coaching adalah kerangka berpikir yang mendukung kekuatan intuitif dan ketrampilan coaching kita (Wilson, 2011). Terdapat banyak model yang dapat digunakan dalam coaching antara lain emotional quotient (EQ), GROW, EXACT, Model Johari Window, Model forming, storming, norming, performing pengembangan tim - Bruce Tuckman, model kepemimpinan situasional Hersey-Blanchard, dan lain-lain. Tulisan ini hanya membahas dua model yaitu EQ dan GROW.

Goal merupakan tujuan yang akan dicapai dalam proses coaching. Ini merupakan tahapan pertama dalam coaching yaitu menentukan apa yang ingin dicapai. Dengan mengetahui tujuan yang ingin dicapai, kita dapat menentukan jalur atau arah yang akan digunakan untuk mencapai tujuan tersebut. Reality (realitas) merupakan eksplorasi tentang 
keberadaan coachee sekarang. Pada tahap ini coachee didorong untuk menemukan kebutuhan yang perlu diungkapkan dan dianalisis. Penggalian secara mendalam terhadap realitas merupakan kunci keberhasilan coaching. Options (opsi) merupakan tahap lanjutan setelah coachee menemukan realitas pada tahap sebelumnya. Dengan adanya realitas yang telah dikembangkan sebelumnya, coachee dapat menentukan opsi atau pilihan-pilihan yang cocok untuk dilakukan. Sementara Will (Kemauan) mencakup tindakan apa yang akan diambil oleh coachee. Ketiga tahap sebelumnya bertujuan untuk menciptakan kesadaran. Setalah kesadaran dicapai, coachee mendapatkan kejelasan yang lebih tinggi, yang pada gilirannya coachee dengan sendirinya termotivasi untuk mengambil tanggung jawab terhadap perubahan yang akan dilakukan.“

Menurut Canfield dan Chee (2011) ada aspek 8 prinsip coaching meliputi; the coaching spirit (semangat coaching), relationship and trust (hubungan dan kepercayaan), asking question and curiosity (bertanya dan rasa ingin tahu), listening and intuition (mendengar dan berintuisi), feedback and awareness (umpan balik dan penyadaran), suggestion and simplification (sugesti dan penyederhanaan), dan accountability and accomplishments (prestasi dan tanggung jawab).

Coach dan mentor seharusnya memiliki karakter sebagai coach dan mentor yang ideal. Karakteristik coach dan mentor yang baik menurut Passmore (2010) diantaranya adalah empati, perspektif, fokus yang jelas, intuisi, obyektif, dan kekuatan untuk memberi tantangan kepada coachee. Lebih lanjut Passmore mengemukakan selain karakteristik tersebut, coach dan mentor harus memiliki beberapa ketrampilan. Ketrampilan yang harus dimiliki antara lain ketrampilan mendengarkan, mengajukan pertanyaan, dan mengklarifikasi sesuai tujuan, strategi, dan tindakan. Whitmore (1997) mengemukakan kualitas seorang pengarah yang ideal diantaranya adalah sabar, lepas bebas, bersifat mendukung, berminat, pendengar yang baik, perseptif, sadar, sadar diri sendiri, atentif, dan retentif.

Berdasarkan beberapa definisi yang telah dikemukakan dibagian terdahulu maka coaching adalah percakapan terstruktur yang menggunakan informasi tentang kinerja yang nyata antara seorang atasan dengan seorang individu (atau tim) yang menghasilkan kinerja yang lebih tinggi. Merujuk pada definisi tersebut di atas, bentuk dari coaching adalah percakapan dan membantu orang yang dibimbing untuk meningkatkan kinerjanya. 


\section{Aktualisasi}

Menurut Maslow (2011) aktualisasi diri merupakan puncak dari perwujudan segenap potensi manusia di mana hidupnya penuh gairah dinamisdan tanpa pamrih, konsentrasi penuh dan terserap secara total dalam mewujudkan manusia yang utuh dan penuh. Orang yang tidak tertekan oleh perasaan cemas, perasaan risau, tidak aman, tidak terlindungi, sendirian, tidak dicintai adalah orang yang terbebas dari meta motivasi (Robert, 1993 : 161). Sedangkan menurut Zuhairini (2000:188) yang dimaksud dengan aktualisasi diri adalah bila manusia itu mampu berkembang secara sempurna dengan cara yang semaksimal mungkin, sebab aktualisasi merupakan bentuk kepribadian yang memiliki karakteristik yang unik.

\section{METODE}

\section{Metode Penelitian}

Penelitian ini menggunakan pendekatan kuantitatif. Menurut Komariah dan Satori (2011:22-25), dikatakan bahwa penelitian kualitatif dapat didesain untuk memberikan sumbangannya terhadap teori, praktis, kebijakan, masalah-masalah sosial dan tindakan. Penelitian kualitatif adalah suatu pendekatan penelitian yang mengungkapkan situasi sosial tertentu dengan mendeskripsikan kenyataan secara benar, dibentuk oleh kata-kata berdasarkan teknik pengumpulan dan analisis data yang relevan yang diperoleh dari situasi yang alamiah.

\section{Populasi dan Sampel}

Menurut Sukmadinata (2011) populasi adalah kelompok besar dan wilayah yang menjadi lingkup. Adapun populasi dalam penelitian adalah alumni Pelatihan Dasar CPNS Golongan III Kabupaten Pulau Morotai Tahun 2021 sebanyak 87 orang.

Sedangkan menurut Sugiyono (2019) sampel adalah bagian dari jumlah dan karakteristik yang dimiliki oleh populasi tersebut. Penarikan sampel menggunakan Probability sample. Probability sample adalah suatu sampel yang ditarik sedemikian rupa, dimana suatu elemen individu dari populasi tidak didasarkan pada pertimbangan pribadi, tetapi tergantung kepada aplikasi kemungkinan. Maka jumlah sampel dalam penelitian ini sebanyak 40 responden.

Karakteristik responden dalam penelitian dapat digambarkan mulai dari jenis kelamin, dan formasi jabatan. Adapun gambaran responden dapat dilihat dalam Tabel 1-2 sebagai berikut: 
Tabel 1

Responden Berdasarkan Jenis Kelamin

\begin{tabular}{|c|l|c|c|}
\hline No & $\begin{array}{c}\text { Jenis } \\
\text { Kelamin }\end{array}$ & Jumlah & $\begin{array}{c}\text { Persentase } \\
(\boldsymbol{\%})\end{array}$ \\
\hline 1 & Laki-laki & 19 & 47,5 \\
\hline 2 & Perempuan & 21 & 52,5 \\
\hline & Total & 40 & 100 \\
\hline
\end{tabular}

Sesuai pengisian kuesioner diketahui responden berdasarkan jenis kelamin laki-laki sebanyak $47,5 \%$ dan responden perempuan sebanyak $52,5 \%$.

Tabel 2

Responden Berdasarkan Formasi Jabatan

\begin{tabular}{|c|l|c|c|}
\hline No & \multicolumn{1}{|c|}{ Pangkat/Gol } & Jumlah & $\begin{array}{c}\text { Persentase } \\
(\mathbf{\%})\end{array}$ \\
\hline 1 & Guru & 7 & 17,5 \\
\hline 2 & Kesehatan & 16 & 40 \\
\hline 3 & Teknis & 17 & 42,5 \\
\hline \multicolumn{2}{|c|}{ Total } & 40 & 100 \\
\hline
\end{tabular}

Berdasarkan data responden sesuai formasi jabatan diketahui tenaga guru sebanyak $17,5 \%$, tenaga kesehatan sebanyak $40 \%$ dan tenaga teknis sebanyak $42,5 \%$.

\section{Teknik Pengumpulan Data}

Teknik pengumpulan data dilakukan untuk memperoleh informasi yang dibutuhkan dalam rangka mencapai tujuan penelitian. Teknik pengumpulan data dalam penelitian adalah kajian kepustakaan diperoleh dari teori dan penelitian terdahulu yang berkaitan dengan objek penelitian, penyebaran kuesioner menggunakan google form dengan menghubungi secara langsung responden via aplikasi WhatsApp serta wawancara kepada penyelenggara pelatihan sebagai narasumber.

\section{Teknik Analisis Data}

Setelah data sudah terkumpul sesuai dengan kebutuhan penelitian, selanjutnya dilakukan analisis data menggunakan deskriptif kualitatif. Penelitian deskriptif kualitatif bertujuan untuk mendeskripsikan dan menggambarkan fenomena-fenomena yang ada di 
lapangan, baik bersifat alamiah maupun rekayasa manusia, yang lebih memperhatikan mengenai karakteristik, kualitas, keterkaitan antar aktivitas (Sukmadinata, 2011).

\section{HASIL DAN PEMBAHASAN \\ Prinsip Coaching Penulisan Aktualisasi}

Hasil penyebaran kuesioner penelitian untuk mengukur persepsi responden tentang prinsip coaching penulisan aktualisasi menggunakan lima skala likert diantaranya sangat setuju nilainya (5), setuju nilainya (4), cukup setuju nilainya (3), kurang setuju nilainya (2) dan tidak setuju nilainya (1). Berdasarkan distribusi jawaban responden prinsip coaching penulisan aktualisasi diketahui bahwa dari 8 (delapan) pernyataan mendapatkan jawaban sesuai kondisi sebenarnya.

Pernyataan pertama saya merasa sangat bersemangat saat melaksanaan coaching, responden memilih sangat setuju sebesar 55\% dan setuju sebesar $45 \%$. Pada pernyataan pertama, coach sudah berhasil memberikan semangat coachee dalam menyelesaikan penyusunan laporan aktualisasinya.

Pernyataan kedua, saya merasa coach dengan tulus membangun hubungan dan kepercayaan dengan baik, mendapat respon sangat setuju sebesar $75 \%$, setuju $20 \%$ dan cukup setuju 5\%. Cocach telah berhasil membangun hubungan dan kepercayaan baik sehinggan menimbulkan rasa nyaman dalam menyusun laporan aktualisasi.

Pernyataan ketiga, saya merasa coach mengajukan pertanyaan yang memberdayakan dan tidak menghakimi coachee, mendapat respon sangat setuju 57.5\%, setuju $37.5 \%$ dan cukup setuju 5\%. Coach telah mampu menyampaikan pertanyaan yang tidak menghakimi sehingga coachee dapat menceritakan kondisi yang dialaminya.

Pernyataan keempat, saya merasa coach lebih banyak mendengar masalah coachee, mendapat respon sangat setuju $42.5 \%$, setuju $45 \%$ dan cukup setuju $12.5 \%$. Pernyataan keempat mendapat respon yang perlu menjadi salah satu evaluasi karena nilai setuju lebih tinggi dari sangat setuju serta mendapat nilai cukup setuju tinggi.

Pernyataan kelima, saya merasa coach memberi umpan balik yang menginspirasi hingga menemukan permasalahan utama yang dihadapi coachee, mendapat respon sangat setuju $62.5 \%$, setuju $32.5 \%$ dan cukup setuju $5 \%$. Coach telah berhasil memberikan umpan balik yang menginspirasi coachee sehingga menemukan permasalahan utama untuk mendapatkan solusinya. 
Pernyataan keenam, saya merasa coach telah memberikan nasihat atas masalah dengan persetujuan coachee, mendapat respon sangat setuju 70\%, sangat setuju 25\% dan cukup setuju 5\%. Coach telah mampu membuat coachee menyadari bahwa masalahnya telah lebih mudah untuk diselesaikan.

Pernyataan ketujuh, saya merasa pernah membuat kesepakatan dan berkomitmen antara coach dan coachee dalam menyusun tujuan serta strategi kedepan, mendapat respon sangat setuju 35\%, setuju 55\%, cukup setuju 7.5\% dan kurang setuju 2.5\%. Pernyataan ketujuh mendapat respon yang perlu menjadi bahan evaluasi karena ada selisih $20 \%$ nilai setuju dengan sangat setuju, serta mendapat nilai kurang setuju sebesar $2.5 \%$. Coach dianggap belum membuat kesepakatan dan berkomitmen antara coach dan coachee.

Sedangkan pernyataan kedelapan, saya merasa coach sangat bertanggungjawab dengan terus mendukung pencapaian coachee pada penyusunan aktualisasi, mendapat respon sangat setuju $57.5 \%$, setuju $40 \%$ dan cukup setuju $2.5 \%$. Coach telah bertanggung jawab dalam mendukung pencapaian coachee selama menyusun laporan aktualisasi.

Berdasarkan hasil temuan dapat disimpulkan bahwa secara umum prinsip coaching penulisan aktualisasi sudah berjalan dengan baik. Tetapi masih ada beberapa aspek yang perlu perkuat lagi diantaranya pernyataan keempat saya merasa coach lebih banyak mendengar masalah coachee dan pernyataan ketujuh saya merasa pernah membuat kesepakatan dan berkomitmen antara coach dan coachee dalam menyusun tujuan serta strategi kedepan. Lebih jelasnya dapat dilihat pada tabel 3 respon atas pernyataan yang disampaikan. 


\section{Tabel 3}

Rekapitulasi Jawaban Prinsip Coaching Penulisan Aktualisasi

\begin{tabular}{|c|c|c|c|c|c|c|}
\hline \multirow{2}{*}{ No. } & \multirow{2}{*}{ Pernyataan } & \multicolumn{5}{|c|}{ Presentase Jawaban (\%) } \\
\hline & & SS & $\mathrm{S}$ & $\mathrm{CS}$ & $\mathrm{KS}$ & TS \\
\hline 1. & $\begin{array}{l}\text { Saya merasa sangat } \\
\text { bersemangat saat melaksanaan } \\
\text { coaching }\end{array}$ & 55 & 45 & & & \\
\hline 2. & $\begin{array}{l}\text { Saya merasa coach dengan } \\
\text { tulus membangun hubungan } \\
\text { dan kepercayaan dengan baik }\end{array}$ & 75 & 20 & 5 & & \\
\hline 3. & $\begin{array}{l}\text { Saya merasa coach } \\
\text { mengajukan pertanyaan yang } \\
\text { memberdayakan dan tidak } \\
\text { menghakimi coachee }\end{array}$ & 57.5 & 37.5 & 5 & & \\
\hline 4. & $\begin{array}{l}\text { Saya merasa coach lebih } \\
\text { banyak mendengar masalah } \\
\text { coachee }\end{array}$ & 42.5 & 45 & 12.5 & & \\
\hline 5. & $\begin{array}{l}\text { Saya merasa coach memberi } \\
\text { umpan balik yang } \\
\text { menginspirasi } \\
\text { menemukan permasalahan } \\
\text { utama yang dihadapi coachee }\end{array}$ & 62.5 & 32.5 & 5 & & \\
\hline 6. & $\begin{array}{l}\text { Saya merasa coach telah } \\
\text { memberikan nasihat atas } \\
\text { masalah dengan persetujuan } \\
\text { coachee }\end{array}$ & 70 & 25 & 5 & & \\
\hline 7. & $\begin{array}{l}\text { Saya merasa pernah membuat } \\
\text { kesepakatan dan berkomitmen } \\
\text { antara coach dan coachee } \\
\text { dalam menyusun tujuan serta } \\
\text { strategi kedepan }\end{array}$ & 35 & 55 & 7.5 & 2.5 & \\
\hline 8. & $\begin{array}{l}\text { Saya merasa coach sangat } \\
\text { bertanggungjawab dengan } \\
\text { terus mendukung pencapaian } \\
\text { coachee pada penyusunan } \\
\text { aktualisasi }\end{array}$ & 57.5 & 40 & 2.5 & & \\
\hline
\end{tabular}

\section{Penerapan Soft Skill Coaching Dalam Penulisan Aktualisasi}

Berdasarkan respon terhadap variabel penerapan soft skill coaching dalam penulisan aktualisasi diketahui bahwa pernyataan pertama saya merasa coach telah melakukan komunikasi dengan baik selama proses coaching berlangsung mendapat respon sangat setuju $62.5 \%$, setuju $35 \%$ dan cukup setuju $2.5 \%$. 
Pertanyaan kedua, saya merasa coach memiliki keterampilan emosional yang baik selama proses coaching berlangsung, mendapat respon sangat setuju $62.5 \%$, setuju $27.5 \%$ dan cukup setuju $10 \%$.

Pernyataan ketiga, saya merasa coach memliki keterampilan berbahasa (pilihan kata) yang baik selama proses coaching berlangsung, mendapat respon sangat setuju 55\%, setuju $40 \%$ dan cukup setuju $5 \%$.

Pernyataan keempat, Saya merasa coach memiliki keterampilan berkelompok tanpa memandang status sosial selama proses coaching berlangsung, mendapat respon sangat setuju $62.5 \%$, setuju $30 \%$ dan cukup setuju $7.5 \%$.

Penyataan kelima, saya merasa coach memiliki etika dan moral yang baik sehingga dapat dijadikan sebagai panutan, mendapat respon sangat setuju $60 \%$, setuju $35 \%$ dan cukup setuju 5\%. Pernyataan keenam, saya merasa coach sangat santun selama proses coaching berlangsung, mendapat respon $47.5 \%$, setuju $45 \%$ dan cukup setuju $7.5 \%$.

Pernyataan ketujuh, saya merasa coach memiliki keterampilan spiritual yang baik, mendapat respon sangat setuju 55\%, setuju $40 \%$ dan cukup setuju 5\%. Sedangkan pernyataan kedelapan adalah saya merasa penerapan metode soft skill coaching sudah berjalan dengan baik, mendapat respon sangat setuju 57.5\%, setuju $40 \%$ dan cukup setuju $2.5 \%$.

Berdasarkan hasil temuan dapat disimpulkan bahwa secara umum penerapan soft skill coaching dalam penulisan aktualisasi sudah berjalan dengn baik tetapi masih perlu penguatan pada pernyataan keenam tentang perilaku sopan santun selama proses coaching berlangsung, serta perlunya peningkatan kompetensi coaching yang dilakukan secara berkesinambungan. Hasil penelitian ini sesuai dengan temuan Fauziatunisa et. al. (2018), bahwa proses coaching yang dimiliki oleh karyawan PT. Sari Ater Hotel dan Resort telah dilakukan dengan baik. Tetapi dengan hasil tersebut perusahaan masih perlu meningkatkan kemampuan karyawan karena masih ada dimensi yang berada dibawah skor ideal.

Sedangkan menurut hasil wawancara dengan penyelenggara tentang pengembangan kompetensi coach agar memiliki kemampuan dalam membimbing peserta atau coachee disesuaikan dengan perkembangan regulasi dan ketersediaan pembiayaan. Lebih jelasnya dapat dilihat pada tabel 4 respon atas pernyataan yang disampaikan. 
Tabel 4.

Rekapitulasi Jawaban Penerapan Soft Skill Coaching dalam Penulisan Aktualisasi

\begin{tabular}{|c|c|c|c|c|c|c|}
\hline \multirow{2}{*}{ No. } & \multirow{2}{*}{ Pernyataan } & \multicolumn{5}{|c|}{ Presentase Jawaban (\%) } \\
\hline & & SS & $S$ & $\mathrm{CS}$ & KS & TS \\
\hline 1. & $\begin{array}{l}\text { Saya merasa coach telah melakukan } \\
\text { komunikasi dengan baik selama proses } \\
\text { coaching berlangsung }\end{array}$ & 62.5 & 35 & 2.5 & & \\
\hline 2. & $\begin{array}{l}\text { Saya merasa coach memiliki } \\
\text { keterampilan emosional yang baik } \\
\text { selama proses coaching berlangsung }\end{array}$ & 62.5 & 27.5 & 10 & & \\
\hline 3. & $\begin{array}{l}\text { Saya merasa coach memliki } \\
\text { keterampilan berbahasa (pilihan kata) } \\
\text { yang baik selama proses coaching } \\
\text { berlangsung }\end{array}$ & 55 & 40 & 5 & & \\
\hline 4. & $\begin{array}{l}\text { Saya merasa coach memiliki } \\
\text { keterampilan berkelompok tanpa } \\
\text { memandang status sosial selama proses } \\
\text { coaching berlangsung }\end{array}$ & 62.5 & 30 & 7.5 & & \\
\hline 5. & $\begin{array}{l}\text { Saya merasa coach memiliki etika dan } \\
\text { moral yang baik sehingga dapat } \\
\text { dijadikan sebagai panutan }\end{array}$ & 60 & 35 & 5 & & \\
\hline 6. & $\begin{array}{l}\text { Saya merasa coach sangat santun selama } \\
\text { proses coaching berlangsung }\end{array}$ & 45.5 & 45 & 7.5 & & \\
\hline 7. & $\begin{array}{l}\text { Saya merasa coach memiliki } \\
\text { keterampilan spiritual yang baik }\end{array}$ & 55 & 40 & 5 & & \\
\hline 8. & $\begin{array}{l}\text { Saya merasa penerapan metode soft skill } \\
\text { coaching sudah berjalan dengan baik }\end{array}$ & 57.5 & 40 & 2.5 & & \\
\hline
\end{tabular}

\section{PENUTUP}

\section{Kesimpulan}

Prinsip coaching penulisan aktualisasi sudah berjalan dengan baik. Tetapi masih ada beberapa aspek yang perlu perkuat lagi diantaranya pernyataan keempat saya merasa coach lebih banyak mendengar masalah coachee dan pernyataan ketujuh saya merasa pernah membuat kesepakatan dan berkomitmen antara coach dan coachee dalam menyusun tujuan serta strategi kedepan.

Kedua, penerapan soft skill coaching dalam penulisan aktualisasi sudah berjalan dengan baik tetapi masih perlu penguatan pada pernyataan keenam tentang perilaku sopan santun selama proses coaching berlangsung, serta perlunya peningkatan kompetensi coaching yang dilakukan secara berkesinambungan. 


\section{Saran}

Berdasarkan hasil penelitian maka saran yang disampaikan kepada Lembaga Pelatihan BPSDM Provinsi Maluku Utara diantaranya (1) Perlunya peningkatan kompetensi coach secara berkesinambungan: (2) Perlu melakukan evaluasi pelaksanaan coaching; (3) Mengambil responden penelitian dari masing-masing coach.

\section{DAFTAR PUSTAKA}

Canfield, J., Chee, P. (2011). Coaching for Breakthrough Success. Jakarta: Kesaint Blanc Elfindri, et al. (2011). Soft Skill untuk Pendidik. Bandung: Baduose Media

Fauziatunisa, H. et al. (2018). Analisis Kemampuan Kerja, Coaching dan Kinerja Karyawan:

$\underline{\text { Satudi Kasus pada Karyawan PT Sarti Ater Hotel dan Resort. Journal of Business }}$ Management Education. Volume 3 No. 3

Goleman, D. (2005). Kecerdasan Emosi: Untuk Mencapai Puncak Prestasi. Terjemahan Alex Tri Kantjono. 2005. Jakarta: PT. Gramedia Pustaka Utama

Jaques, E, D. Clement, S.D. (1994). Executive Leadership, Scason Hall Publisher Ltd, Second Printing. Cambridge: Massachusetts USA

Komariah, A., Satori, D. (2011). Metode Penelitian Kualitatif. Bandung: Alfabeta.

Maslow, A.H. (2010). Motivation and Personality. Jakarta: Rajawali

Mulyono, I. (2011). Dari Karya Tulis Ilmiah Sampai dengan Soft Skills. Bandung: Yrama $\underline{\text { Widya }}(2)$

Sailah, I. (2008). Pengembangan Soft Skills di Perguruan Tinggi. Jakarta: Direktorat Jenderal Pendidikan Tinggi

Salim, G. (2014). Effective Coaching. Jakarta: PT. Buana Ilmu Populer

Sugiyono. (2019). Metode Penelitian Kuantitaif, Kualitatif dan R \& D. Bandung: Alfabeta.

Sukmadinata, N.S. (2011). Landasan Psikologi Proses Pendidikan. Bandung: Remaja $\underline{\text { Rosdakarya }(2)}$

Whitmore, J. (1997). Coaching for Performance, Seni Mengarahkan untuk Mendongkrak Kinerja. Jakarta: Gramedia Pustaka Utama. (2)

Zuhairini. (2000). Filsafat Pendidikan Islam. Jakarta: Bumi Aksara. 